\title{
Genre Analysis of Saudi Universities' Websites: Analysis of Rhetorical Moves and Discursive Strategies for Marketization Purposes
}

\author{
Ahmad I. Alhojailan ${ }^{1}$ \\ ${ }^{1}$ Department of English Language and Translation, College of Arabic Language and Social Studies, Qassim \\ University, Buraydah, Saudi Arabia \\ Correspondence: Ahmad I. Alhojailan, Department of English Language and Translation, College of Arabic \\ Language and Social Studies, Qassim University, Buraydah, Saudi Arabia. E-mail: a.alhojailan@qu.edu.sa
}

Received: July 11, $2020 \quad$ Accepted: August 13,2020 Online Published: August 18, 2020

doi:10.5539/ijel.v10n6p65 URL: https://doi.org/10.5539/ijel.v10n6p65

\begin{abstract}
The field of education has experienced numerous shifts, including internationalization, greater competitiveness and collaboration, and globalization. Today, higher education branding has become a common trend. To differentiate themselves in the business world, universities apply different branding techniques and this study aims to examine how some Saudi universities advertise themselves. Incorporating Critical Discourse Analysis (CDA), the study analyzes the "About Us" sections of seven Saudi universities' websites to explore the rhetorical moves and discursive strategies employed for marketization purposes. The selected universities all featured in the top 1000 universities in the QS World University Rankings 2020. The results show diversity in these universities' choices of implemented rhetorical moves and sub-moves. They used eight rhetorical moves and 13 sub-moves, with only one of these sub-moves occurring on all seven universities' websites. The discursive strategies were employed to foster self-promotion, while the results demonstrated that the "About Us" sections of all universities were promotional. Finally, some recommendations are provided for universities for marketization purposes if they want to be global and compete with other international universities in the higher education market, in addition to providing suggestions for future studies.
\end{abstract}

Keywords: academic web genre, Saudi university, corpus-based study, promotional discourse, genre analysis

\section{Introduction}

Universities' role used to be to retain their esteemed reputation and contribute to society by dissipating awareness, and the single and worthy goal of higher education was to establish non-utilitarian awareness, promote human growth, and generate great scholars (Askehave, 2007; Kwong, 2000; Zhang, 2017). Globalization has affected education in various ways, including the internationalization of higher education institutes to serve students from around the globe. International study is now available to all, and the number of colleges and universities has increased. In Saudi Arabia, for example, the number of universities and colleges has increased 226\% between 2000 and 2020. Osman (2008) claims that colleges and universities began advertising to make themselves more appealing and interesting to national and international students for the purpose of encouraging prospective students to apply.

To succeed in this environment of strong competition among higher education institutes, universities are implementing several techniques and approaches to satisfy students' needs, one of which is to use their websites to offer relevant information to prospective students. The medium by which universities communicate with prospective students has changed over time. Poonchako (2017) notes that "in the past, university brochures and prospectuses were applied as a medium to connect between the students and the universities. However, nowadays the universities have more channels to contact to the students and the vital medium is the internet" (p. 1). Websites require the interaction of at least two persons: the information provider and information receiver. The information provider must provide the information that meets the needs of the information receiver. Symonenko (2007) states that "there has been a trend towards greater similarity, or conventionalization, in the organization of website content" (p. 4), perhaps because such similarity helps users to easily navigate and explore the website. 
Various studies (e.g., Fairclough, 1993; Xiong, 2012; Yang, 2013; Kheovichai, 2014) have pointed out the trend whereby universities use marketing strategies on their websites, with previous studies exploring different aspects of this phenomenon. Fairclough (1993), Askehave (2007), and Teo (2007), for example, studied prospectuses; Giannoni (2018) analyzed "About Us" statements; and Mayr (2008) investigated university strategy documents, to name but a few.

Since creating a successful brand is a significant task for every university whose success relies on its students (Rust \& Uys, 2014; Watkins \& Gonzenbach, 2013), the current study investigates "About Us" webpages in seven different Saudi universities to explore how they advertise themselves. The "About us" section was chosen because this is an example of a webpage that combines academic concerns with business concerns and because it is one of the webpages visited by prospective students. The selected universities are: King Fahd University of Petroleum \& Minerals, King Saud University, Umm Al-Qura University, Imam Abdulrahman Bin Faisal University, Prince Mohammad bin Fahd University, Islamic University of Madinah, and Princess Nourah bint Abdulrahman University. These universities were selected because they all featured among the best 1000 universities in the QS World University Rankings 2020.

Saudi Vision 2030 has accentuated that Saudi universities should stop relying on government funding and instead rely on themselves to diversify their funding channels. Since accepting national and international students is one way to increase their funds, these seven universities, as well as other Saudi universities, must ensure that they remain at a level with other universities in Asia in particular, and in the world in general.

It is hoped that the study's findings will be of importance at different levels:

1) By helping higher education institutions to build their identities to attract prospective national and international students.

2) By demonstrating how Saudi universities identify and represent themselves on the Internet, a medium that is commonly used in the fields of marketing and education.

3) For use in writing and reading courses to practice writing persuasive texts and to study the styles adopted in those texts.

On that basis, this study attempts to answer the following research questions:

1) What are the employed rhetorical moves and communicative purposes of the "About Us" sections of the universities under investigation?

2) What discursive strategies in terms of lexical, grammatical, and syntactic choices are adopted to achieve these communicative purposes?

3) What is the impact of the marketization trend on this genre?

\section{Literature Review}

\subsection{Definition of Genre}

According to Bhatia (2002), genre is defined on the basis of the rhetorical or communication purpose of a text used in a particular context among members of a specific discourse community, and as a result, a communicative purpose is an essential characteristic of a genre (Bhatia, 1997). Bhatia (1997) described genres as:

The use of language in conventionalized communicative settings. They serve the goals of specific discourse communities, tend to establish relatively stable structural forms and constrain the use of lexicogrammatical resources in expressing these forms. (p. 181)

Swales (1990) defined genre as follows:

A genre comprises a class of communicative events, the members of which share some set of communicative purposes. These purposes are recognized by the expert members of the parent discourse community and thereby constitute the rationale for the genre. This rationale shapes the schematic structure of the discourse and influences and constrains the choice of content and style. (p. 85)

Genre, therefore, is an essential factor in both professional and scholarly communication, provided that particular professional participants or discourse communities use a specific collection for communicative purposes (Bhatia, 1997).

\subsection{Academic Genres}

Various studies have been conducted to analyze the moves employed in different academic genres. To name but a 
few, Cross and Oppenheim (2006) analyzed the abstracts of protozoology studies, Ding (2007) explored the moves employed by dental and medical school applicants, Samraj and Monk (2008) examined the application essays of applicants to the Electrical Engineering, Business Administration, and Linguistics programs of a single university, and Alharbi (2016) examined Arabic research articles in Islamic studies.

Regarding universities' websites and webpages, different studies have examined different aspects of language, usage, and application in various settings for the purpose of understanding this genre in comparison with other academic disciplines. Tomarkova (2015), for example, explored the websites of some Czech, British, and American universities to compare and contrast their multimodal features. He found that cultural and social contexts affect the universities' representation. Zhang and O'Halloran (2013) also investigated the website of the National University of Singapore to identify the strategies that enabled the university to become a regional competitor rather than a domestic entity and found that during the past decade, the university's website has changed from an information-based to a customer-based strategy. Additionally, Jessee (2009) studied students' profiles found on various universities' websites and noted that the profiles are working to promote universities. Finally, it can be argued that from these examples, and others, university websites can be used as a means of promotion.

\subsection{Web as a Medium}

According to Schlegelmilch and Pollach (2005), there are different reasons why universities prefer to use the Internet, including its high level of accessibility at a low cost. Toms and Campbell (1999) also claim that the structure helps communicate the purpose of the document faster than the actual content. According to Dillon and Vaughan (1997), experienced users, unlike novice ones (who place heavy emphasis on the structural elements of the website to understand its content), rely on their knowledge of semantic clues to understand the content of a website. Moreover, Shepherd and Watters (1998) claim that both the content and form (structure) of a webpage "provide a familiar and strong metaphorical reference for users and transcend changes in functionality" (p. 101).

\subsection{Marketization in Higher Education Discourse}

Xiong (2012) analyzed 48 academic job ads published in a Chinese-language newspaper and explored the discourse strategies and rhetorical moves employed in those advertisements as a way to understand the Chinese universities. He claims that the "establishing credentials" move plays an essential role in advertising higher education institutions. He also found that branding strategy aimed at publicizing academic posts as well as promoting the institutions' venue.

Examining the lexico-grammatical features and generic structure of "Why Choose Us?" texts in some university websites, Yang (2013) noted that the promotional genre has been embedded in the academic genre, and texts are now used to advertise universities so that more students are recruited. He also listed the following six moves used in "Why Choose Us?" sections: establishing a distinguished status; presenting a leading role in research; ensuring excellent teaching quality; enjoying a friendly environment; offering attractive incentives; and ending with suggestions. This study indicates that the university is no longer simply an intellectual institution but a product that needs to be offered to its student customers.

For the purpose of exploring how universities use language to portray themselves on institutional websites, how they develop a relationship with prospective students, and how they create their institutional image, Hoang and Rojas-Lizana (2015) examined the websites of two universities in Australia. The findings demonstrated that the websites use promotional discourse, and this was attributed to the effect of marketization and globalization.

Remaining with universities in Australia, Giannoni (2018) compared the "About Us" sections on the websites of an Australian university and a company and found that both websites share the values of any commercial organization. Furthermore, analyzing the "About Us" section in five Chinese universities, Zhang (2017) claims that they consist of seven moves represented by 11 subsections. Those moves are: welcoming (e.g., president's message); establishing credentials (e.g., history, publications, overview, facts \& figures); describing administration (e.g., leadership); attracting attention (e.g., university logo, motto, video, song); providing more services (e.g., international student services, facilities available); locating the service (e.g., visiting the campus); and willingness for response (e.g., contact us).

As can be seen from the studies mentioned above, the rhetorical moves and discursive strategies of the Saudi universities' websites for marketization purposes have not been investigated yet. As a result, this study will be focusing on how such universities advertise themselves and what branding techniques they use. Gaining an understanding of this issue will add to the already existing body of research in the area of higher education branding. 


\section{Methodology}

\subsection{Method}

The current study applied the genre-analytical approach as suggested by Bhatia (1993) and Swales (1990), and therefore, the move structure of this genre will be identified. A move, according to Swales (2004), is a "cognitive structuring" or "discoursal or rhetorical unit" that serves "a coherent communicative function" (p. 228). In this study, both obligatory and optional moves will be studied and listed to help identify some of the generic characteristics; namely, text structure, communicative purposes, and rhetorical moves.

Since language is "a form of social practice" (Fairclough, 2001, p. 18) and "a socially and historically situated mode of action" (Fairclough, 1993, p. 134), a critical discourse analysis (CDA) paradigm plays an essential role in studying genre. Since genre is a form of utterance and it should not be studied exclusive from its social contexts (Berkenkotter \& Huchin, 1993), the three stages of CDA (description, interpretation, and explanation) will give us a sociolinguistic perspective on the marketing impact of university websites.

\subsection{Universities}

In the current study, the "About Us" section has been selected as the focus because such sections are:

an essential component found in virtually all university website homepages, which gives an overview about the university as well as some fast facts such as history, administration, anthem, logo, etc. Since it is probably the first section that most visitors will click on, it constitutes the most representative part in the homepage, fully demonstrating the distinctive generic characteristics of homepage as well as the unique identity of each university. (Zhang, 2017, p. 67).

The study corpus consists of "About us" section texts from seven universities in Saudi Arabia: King Fahd University of Petroleum \& Minerals, King Saud University, Umm Al-Qura University, Imam Abdulrahman Bin Faisal University, Prince Mohammad bin Fahd University, Islamic University of Madinah, and Princess Nourah bint Abdulrahman University. All seven universities featured in the top 1000 universities in the QS World University Rankings 2020. Although there were three further Saudi universities on that list, they were excluded because they did not have "About Us," "About," or "About (the name of the university)" sections on their websites. More information about the national and international ranking of the universities investigated in this study can be found in Table 1 .

Table 1. Information about the universities and their national and international rankings

\begin{tabular}{llll}
\hline University & Acronym & $\begin{array}{l}\text { Rank among universities in } \\
\text { Saudi Arabia }\end{array}$ & $\begin{array}{l}\text { Rank among universities around } \\
\text { the world }\end{array}$ \\
\hline King Fahd University of Petroleum \& Minerals & KFYPM & 2 & 186 \\
King Saud University & KSU & 3 & 287 \\
Umm Al-Qura University & UAU & 4 & 474 \\
Imam Abdulrahman Bin Faisal University & IAU & 5 & $521-530$ \\
Prince Mohammad bin Fahd University & PMU & 7 & $751-800$ \\
Islamic University of Madinah & IU & 8 & $801-1000$ \\
Princess Nourah bint Abdulrahman University & PNU & 10 & $801-1000$ \\
\hline
\end{tabular}

\section{Findings and Discussion}

Analyzing the texts of the "About Us" sections on seven Saudi universities' websites discloses that there are eight moves and 12 subsections. More information about these moves and subsections can be found in Table 2. 
Table 2. Information about the moves and subsections of "About Us" sections

\begin{tabular}{|c|c|c|c|}
\hline Move & Subsection title & Other given names & Optional / Obligatory \\
\hline \multirow[t]{2}{*}{ Welcoming } & President's message & $\begin{array}{l}\text { Rector's Message / Message from the UQU President / Statement } \\
\text { of the university president / The University rector message / } \\
\text { University rector's office }\end{array}$ & Optional \\
\hline & Vision, mission, values & $\begin{array}{l}\text { Mission \& Vision / Mission / Vision, mission, and goals / Goals / } \\
\text { Key responsibilities }\end{array}$ & \\
\hline \multirow[t]{6}{*}{ Establishing credentials } & Overview & Overview / About the university & Optional \\
\hline & History & $\begin{array}{l}\text { History \& philosophy / History / Evolution / History of the } \\
\text { university }\end{array}$ & \\
\hline & Facts \& figures & UQU Statistics / University observatory / Statistical Report / & \\
\hline & /statistics & PNU in numbers & \\
\hline & Publications & Publications \& Presentations & \\
\hline & Quality assurance & $\begin{array}{l}\text { Second strategic plan / Strategic planning resources / Executive } \\
\text { plan }\end{array}$ & \\
\hline $\begin{array}{l}\text { Describing } \\
\text { administration }\end{array}$ & Leadership & $\begin{array}{l}\text { Administration / Organization / Organizational structure / } \\
\text { Organizational structure of the university / University } \\
\text { administrations / University council / University senate / } \\
\text { University council members / Deanships / Associate deanships } \\
\text { / University vice-rectorates / Rules and regulations / Scientific } \\
\text { council / Policies and Procedures }\end{array}$ & Optional \\
\hline Offering extra services & Facilities available & Defining Characteristics / Hospitals / University centers & Optional \\
\hline Locating the service & Visitors & University Geographical sites / Defining Characteristics & Optional \\
\hline Soliciting responses & Contact us & & Optional \\
\hline $\begin{array}{l}\text { Showing financial } \\
\text { security }\end{array}$ & University endowment & Awqaf (Arabic word for charitable endowments) & Optional \\
\hline Protecting user's privacy & Privacy policy & Copyright $\&$ Disclaimer / Terms of use / Privacy Policy & Optional \\
\hline
\end{tabular}

As seen in Table 2 above, all the subsections that have the same aim were grouped in one move. Only the "Defining characteristics" subsection was categorized in two moves, "Offering extra services" and "Locating the service," since the content of this subsection can be applied to both moves. Additionally, all the moves are optional here; in other words, not all the moves and subsections appeared in the "About Us" sections of all seven universities" websites. Furthermore, the "Describing administration" move has the highest number of webpage names describing its purpose, while the "Soliciting responses" move has the lowest number.

Unlike Zhang's (2017) study, the Saudi universities did not include the "Attracting attention" move in the "About Us" sections of their Internet websites, perhaps because the motto, song, and video (which are included in the "attracting attention" move in Zhang's study) are not common in Saudi culture. Exploring all 29 Saudi universities that currently exist in the country, only one university (not included in the current study) has a song written exclusively for it.

As shown in Table 3, some universities have similar moves and subsections, while others have different moves and subsections or simply lack some of those moves and subsections. It is clear that Prince Mohammad bin Fahd University has the highest number of subsections (11), while Imam Abdulrahman Bin Faisal University has the lowest number (6), which is almost half the number of subsections in the university with the highest number. 
Table 3. Subsections of the "About Us" sections of all universities

\begin{tabular}{|c|c|c|c|c|c|c|}
\hline $\begin{array}{l}\text { King Fahd } \\
\text { University of } \\
\text { Petroleum \& } \\
\text { Minerals }\end{array}$ & $\begin{array}{l}\text { King Saud } \\
\text { University }\end{array}$ & $\begin{array}{l}\text { Umm Al-Qura } \\
\text { University }\end{array}$ & $\begin{array}{l}\text { Imam } \\
\text { Abdulrahman Bin } \\
\text { Faisal University }\end{array}$ & $\begin{array}{l}\text { Prince } \\
\text { Mohammad bin } \\
\text { Fahd University }\end{array}$ & $\begin{array}{l}\text { Islamic } \\
\text { University of } \\
\text { Madinah }\end{array}$ & $\begin{array}{l}\text { Princess Nourah } \\
\text { bint Abdulrahman } \\
\text { University }\end{array}$ \\
\hline $\begin{array}{l}\text { Vision, mission, } \\
\text { values }\end{array}$ & History & Overview & $\begin{array}{l}\text { Vision, mission, and } \\
\text { values }\end{array}$ & Overview & $\begin{array}{l}\text { About the } \\
\text { university }\end{array}$ & $\begin{array}{l}\text { The University } \\
\text { rector message }\end{array}$ \\
\hline $\begin{array}{l}\text { History \& } \\
\text { philosophy }\end{array}$ & $\begin{array}{l}\text { Rector's } \\
\text { Message }\end{array}$ & $\begin{array}{l}\text { Message from the } \\
\text { UQU President }\end{array}$ & Goals & Administration & $\begin{array}{l}\text { Vision, mission, } \\
\text { and goals }\end{array}$ & $\begin{array}{l}\text { History of the } \\
\text { university }\end{array}$ \\
\hline Organization & $\begin{array}{l}\text { Mission \& } \\
\text { Vision }\end{array}$ & Mission & Key responsibilities & Vision \& Mission & $\begin{array}{l}\text { Statement of the } \\
\text { university } \\
\text { president }\end{array}$ & $\begin{array}{l}\text { Vision, mission, and } \\
\text { goals }\end{array}$ \\
\hline $\begin{array}{l}\text { Second strategic } \\
\text { plan }\end{array}$ & Hospitals & $\begin{array}{l}\text { Organizational } \\
\text { structure }\end{array}$ & University council & Evolution & $\begin{array}{l}\text { Organizational } \\
\text { structure of the } \\
\text { university }\end{array}$ & $\begin{array}{l}\text { University council } \\
\text { members }\end{array}$ \\
\hline Visitors & $\begin{array}{l}\text { University } \\
\text { Endowment }\end{array}$ & Strategic plan & $\begin{array}{l}\text { Strategic planning } \\
\text { resources }\end{array}$ & $\begin{array}{l}\text { Defining } \\
\text { Characteristics }\end{array}$ & $\begin{array}{l}\text { University } \\
\text { senate }\end{array}$ & Associate deanships \\
\hline Contact us & Contact Us & Executive plan & $\begin{array}{l}\text { University } \\
\text { observatory }\end{array}$ & Deanships & $\begin{array}{l}\text { Scientific } \\
\text { council }\end{array}$ & $\begin{array}{l}\text { University } \\
\text { vice-rectorates }\end{array}$ \\
\hline \multirow[t]{4}{*}{ Privacy policy } & $\begin{array}{l}\text { Copyright \& } \\
\text { Disclaimer }\end{array}$ & UQU Statistics & & $\begin{array}{l}\text { Publications \& } \\
\text { Presentations }\end{array}$ & $\begin{array}{l}\text { Rules and } \\
\text { regulations }\end{array}$ & $\begin{array}{l}\text { University } \\
\text { administrations }\end{array}$ \\
\hline & Terms of use & $\begin{array}{l}\text { University } \\
\text { Geographical sites }\end{array}$ & & Endowments & Awqaf & $\begin{array}{l}\text { University rector's } \\
\text { office }\end{array}$ \\
\hline & $\begin{array}{l}\text { Privacy } \\
\text { Policy }\end{array}$ & & & $\begin{array}{l}\text { Policies and } \\
\text { Procedures }\end{array}$ & & University centers \\
\hline & & & & $\begin{array}{l}\text { Contact Us } \\
\text { Statistical Report }\end{array}$ & & PNU in numbers \\
\hline
\end{tabular}

The texts in the subsections of each move will now be analyzed to explore how universities marketize themselves in those texts, the relationships between universities and students, and the discursive strategies employed by the rhetorical moves.

\subsection{Welcoming}

One of the subsections in this move is the president's message. Out of seven universities, four include a welcome message from the university president, and its ordering shows its significance; it is placed first in order in one university, second in two universities, and third in one university. Zhang (2017) also noted that the president's message "is gaining popularity and has been included in a growing number of university website homepages" and that it aims to "communicate the university's friendly and welcoming attitude to the readers, thus helping to build the first contact between the university and the potential students" (pp. 69-70).

A close reading of the presidents' messages allowed us to identify two main components: mission of education and strength of university. There are, of course, other components exclusive to some universities. In his message, for example, the KSU president invited students to join the university; the UAU president discussed its location and the advantage of its location near the House of God "Kaaba"; and finally, the IU president pointed out that the university has received special attention from all previous kings including the current king. The UAU president's discussion of location might be an invitation to all Muslim students worldwide to enroll there. Similarly, the IU president's highlighting of the attention the university has received from kings of the country might be an indication that the university is a prestigious one.

Concerning the discursive strategies, both authoritative and conversational discourse can be observed. Han (2014) claimed that the president, as the authoritative body, is responsible for ensuring the conformity of students with national philosophies/ideologies and compliance to teachers. The authoritative discourse can be noted in the employment of a third-person subject, ideological education, and reference to the leadership/kings of the country. These three practices are illustrated below:

\section{A. Third-person subject}

- KSU aims to disseminate and promote knowledge in Saudi Arabia. (KSU)

- Umm Al-Qura (Mother of Villages, a name given to Makkah), the city to which Muslims turn, in which lies the Kaaba; the place of revelation. (UAU) 
- Islamic University is an educational institution of Saudi origin, universal message. (IU)

With the exception of UAU, the presidents of the other universities used the names of the universities numerous times as the subject of the sentences in their messages. Doing so, according to Connell and Galasinski (1998), creates an authorless discourse. Additionally, only the president of KSU used its acronym in his message. The presidents may have wanted to be as friendly with readers (prospective students) as possible.

\section{B. Ideological education}

- ... for serving our homeland and society through this university. (UAU)

- ... to develop education besides achieving comprehensive and sustainable development in our blessed country. (PNU)

- Islamic University is an educational institution of Saudi origin. (IU)

- KSU aims to disseminate and promote knowledge in Saudi Arabia. (KSU)

As can be seen from the statements above, all the presidents accentuated in their messages the importance of teaching students as a means to serve the country. They did so either explicitly by mentioning the name of the country (e.g., Saudi, Saudi Arabia), or implicitly by referring to the country in other words (e.g., our homeland, blessed country).

\section{Referring to the leadership of the country}

- Islamic university, since its founding in 1381 , has received the attention of the leaders of this country. (IU)

- ... in order to achieve the national visions and objectives aspired to by our good leadership. (UAU)

The reference to the leadership of the country by the university presidents could be a sign that the university is dedicated to the agenda of the nation and its allegiance to the leadership of the government.

Regarding the conversational discourse, Fairclough (1992) states that the most noticeable pattern of discursive shifts caused by the commodification of everyday activities is conversationalization. He also notes that conversationalization means "the simulation of private, face-to-face, person-to-person discourse in public mass-audience discourse-print, radio, television" (Fairclough, 1995, p. 80). The rhetorical practices representing the conversational discourse in the presidents' messages are clearly observed in the uses of first-person/second-person pronouns. The following are some examples of this point:

- I can say with certainty that at KSU, you will find the opportunities needed to learn, innovate and create. (KSU)

- We must also realize the significance of the responsibility that we have been entrusted with and the functions we are in charge of as a team and as a system within this academic edifice. (UAU)

- We undertake to prepare constituents of education, innovation and scientific research. (PNU)

These examples show that the university presidents tend to use the pronoun "we" more than the pronoun "I". The use of the pronoun "we" here could be an attempt by the respective presidents to show the readers (prospective students) that the message comes from themselves, faculty members, employees, and the university as an institution. Additionally, in advertising, according to Muhlhausler and Harre (1990), it is common to present the service providers as a team composed of different persons. Finally, the university presidents' use of the pronoun "I" could be an attempt to foster a relationship with prospective students and show that they are friends (Zhang, 2017).

The other subsection in the Welcoming move is "Vision, mission, and values." Surprisingly, this is the only subsection that featured on all seven universities' websites. According to Mišić-Ilić (2014), the university's mission statement "has been recognized as especially indicative regarding the articulation of values, an expression of what a university stands for, aims at, strives to do and how it does it" and it can be demonstrated as "constructing a complex image of universities on the one hand as of academic educational and research institutions, but on the other, increasingly and more significantly, as of specific market-oriented service institutions" (p. 171). The following issues have been the focus of this subsection.

A. Education and research

All the universities accentuated the importance of education (teaching and learning) and scientific research, contrary to the Serbian private universities in Mišić-Ilić's (2014) study, which focused solely on education. Mentioning both education and research activities might be an indication that universities are interested in enrollments from both undergraduate and graduate students (their academic programs mostly necessitate 
research activities). Examples are as follows:

- To provide distinctive education, produce creative research. (KSU)

- Providing creative knowledge, research, and professional services. (IAU)

- It is a comprehensive university for women, which is characterized by its educational leadership and scientific research. (PNU)

\section{B. Society}

All the Saudi universities in the current study proclaim their social aspect, its significance, and their commitment to contributing to its development and progress. The following are some examples:

- Our mission has three key components, teaching, research, and community service. (KFUPM)

- Providing creative knowledge, research, and professional services with effective community partnerships. (IAU)

- Transform the graduate to play a pioneering and leading role in the community. (PMU)

Finally, out of the seven universities, only four mentioned the international dimension. The presence of international terminology could be considered an attempt by these universities not to limit themselves to the local dimension, but to become a player in global education.

\section{Education as a lifestyle}

Most of the universities in the current study limited themselves to providing help in education, research, and community service. However, PMU is the only university that considered education and its effect as a lifestyle and experience even after graduation.

- Transform the graduate to play a pioneering and leading role in the community, enabling him or her to take responsibilities and contribute to solving problems through innovative thinking, collective work, reflection and self-development. (PMU)

The university here is making an effort to position itself in a global community rather than a national one in which the graduates will be fine-tuned to the different forms of marketized requirements that this would bring about.

\subsection{Establishing Credentials}

According to Bhatia (1993), establishing credentials is one of the main features in advertising genres. This genre gains its importance because its writers do their best to make their product "not just a solution but also the best solution" to the readers' problems (Jordon, 1986, p. 36). Therefore, the purpose of this move "not only informs the readers of the strength of the universities, such as the reputation and achievements, but also helps to promote the universities' Unique Selling Points (USPs)" (Zhang, 2017, p. 71).

In the current study, this move is divided into five sub-moves: Overview, History, Facts \& figures/statistics, Publications, and Quality assurance.

\subsubsection{Overview \& History}

Because, in the universities under study, the Overview and History sub-moves mostly share the same information, they were placed in one group. For the purpose of marketization, the following discursive strategies were detected: stating administrative status and highlighting internationalization.

\section{A. Stating administrative status}

- The vast petroleum and mineral resources of the kingdom pose a complex and exciting challenge for scientific, technical and management education. To meet this challenge, the University has adopted advanced training in the fields of science, engineering, and management as one of its goals in order to promote leadership and contribution to the national economy. (KFUPM)

- In 1369 A.H., King Abdulaziz ordered the establishment of the College of Shari ah in Makkah. In so doing, it became the first higher education institution in the kingdom, the nucleus for Umm Al-Qura University, and the main college at this university. (UQU)

- It has acquired a superior status as an academic institution that has a great reputation with regard to Shari'ah sciences, education, and Islamic studies. (UQU)

The previous excerpts show that some universities wanted to distinguish themselves by mentioning some interesting facts about themselves. KFUPM, for example, wanted to be known as a leading university in science, 
engineering, and management, while UQU wanted to be known as the first university established in the country and for focusing mainly on Islamic studies.

\section{B. Highlighting internationalization}

- Islamic University of Madinah in Saudi Arabia is an international Islamic institution in its goal and Saudi Arabian in its affiliation. (IU)

Only one university used the word "international" in its Overview and History subsections. Since internationalization is becoming a trend in higher education, using the word "international" is an effective technique to enhance market profile and international image (Mazzarol, 1998). This strategy shows that the university is reacting to the market trend and adds value to the credentials of the university (Zhang, 2017).

\subsubsection{Facts \& Figures/Statistics}

Although only four universities included this sub-move on their websites, one of the interesting observations for this sub-move is the huge difference among universities in terms of its text. PNU and UAU, for example, mostly used tables to write selective information about the number of students, faculty members, programs, colleges, labs, centers, and admission info, which could fit on one page. On the other hand, IAU and PMU used photos, images, maps, graphs, and charts and IAU spent approximately 50 pages on writing this sub-move, whereas PMU wrote it in 262 pages. The latter two universities included information similar to that in the first two universities in addition to the physical plant, academic achievements, information technology achievements, student affairs, learning resource center (LRC) achievements, human resources, professional development achievements, student training, employee demographics, alumni events, scientific publication, and patents.

It is important to include this sub-move on universities' websites since it can be used for marketization purposes. International prospective students, for example, can examine the number of international students and their nationalities, and seeing that there are students from their own countries might create a friendly relationship with the university.

\subsubsection{Publications}

Only PMU included this subsection, which included information on the university's newspaper (both in Arabic and English), fees, and some general information about the university. Despite that, the current study investigated many academic journals in the universities, but these were not mentioned at all in this sub-move, perhaps because the university's publications are "rare to see ... in the About Us section" (Zhang, 2017, p. 73).

\subsubsection{Quality Assurance}

Only three universities discussed quality assurance through their strategic plans: KFUPM, UQU, and IAU. Including this sub-move helps universities advertise by showing readers (prospective students) the university's priorities, goals, and the plan to achieve them. The following excerpts are some examples:

- KFUPM has gone through its first strategic plan that had a time frame of 2006-2011. The plan had many successes, initiatives and accomplishments, and some shortcomings. However, the potential of our University and our ambitions for it are far greater. We are blessed with quality people at KFUPM; faculty, staff, and students, with whom we can reach better and higher grounds. (KFUPM)

- Focusing on the quality of education and educational programs and their compatibility with the needs of the market and the programs of Saudi Vision 2030. (UQU)

\subsection{Describing the Administration}

In this move, the administration, organizational structure of the university, university council members, deanships, university vice-rectorates, and scientific council are introduced. University presidents are appointed by the king of the country, which means that university leaders are accredited by the government and hence this move gains its importance.

The universities in the current study have some differences in terms of this move, consisting of only one of either texts, charts, texts and images, or a table. Additionally, with the exception of only one university, none of the universities listed the names and titles of their presidents, unlike in Zhang's (2017) study where all the universities' presidents and titles were mentioned.

Moreover, imitating some elite universities around the world (e.g., Harvard, Oxford, and MIT), only one university (PMU) provided a picture and curriculum vitae of its president in this move. Furthermore, only PMU provided the administrative offices (president and vice-presidents) with their contact numbers. Providing the contact numbers could be an attempt by the university to make this move more "conversationalized" and 
"personalized" for readers since they may easily locate the contact of the university administration (Fairclough, 1995, p. 80).

\subsection{Offering Extra Services}

Here, the term "service" goes beyond the educational services to also include the support services provided by the university. It is important to discuss these support services because, as Osman (2008) claims, good programs are the outcome of good facilities. Additionally, providing extra services - beyond the educational ones - is a kind of marketization strategy (Askehave, 2007).

Three of the universities have this move in the "About Us" section. Analyzing them, the universities presented themselves as suppliers of services, as shown in the following excerpts:

- The university campus has been designed with care to provide facilities for a full range of academic and student services in a manner that recognizes and maintains the culture and religious values of the Kingdom. (PMU)

- The LRC also provides learning enrichment services in mathematics, reading, writing, and study skills to ensure students' success of the PMU's learning-centered approach to education. (PMU)

- In addition to scholarship and research, King Saud University provides health and social services to the entire Saudi community, as extending and expanding such services are an essential component of KSU's comprehensive development plans. (KSU)

- As a result of the importance of strong family relations and its impact on society's unity, Princess Nourah Bint Abdulrahman University established the Family Consulting Center while admitting its role in community service under the slogan: "A united family, a safe society". (PNU)

- A specialized center which is established to support students with special needs through providing high quality and comprehensive services related to academic, administrative, psychological, social, and technical aspects. (PNU)

The above excerpts include linguistics terms that present universities as service providers (e.g., provide, support). The services provided also cover various fields (e.g., education, health, family issues, and students with special needs). The interest in providing services in various fields could be considered a marketing strategy by universities to show prospective students that they (universities) will provide them (students) with all the services and help that they require.

\subsection{Locating the Service}

The purpose of this move is to familiarize prospective students and visitors with the university's location and campus directions. Three universities included this move in the "About Us" section of their websites. Although highlighting the good location of the university and the interesting campus surroundings is now a trend among universities (Askehave, 2007; Osman, 2008; Xiong, 2012), only one of the three universities that included this move applied this strategy. UQU, for example, simply included a map of the western part of the country where the main campus and university branches are located. Additionally, KFUPM only included texts about the city (where the university is located), the country, big cities in the country, climate, and religion.

On the other hand, PMU included a map and a text. The university discussed the advantages of its location, as can be seen in the following excerpt:

- The university's location in the Eastern Province is particularly appropriate to serving the business, industrial and community needs of the KSA.

Unlike the universities in Zhang's (2017) study, the universities in the current study did not provide either campus maps or pictures of the surroundings in this move.

\subsection{Soliciting Responses}

Osman (2008) notes that this move is considered a promotional strategy since prospective students engage in contact with the university through this move to ask for further information and clarification. However, only three universities include this move in their "About Us" section. Additionally, the information included varied from one university to another. KSU, for example, only included the mailing address, a telephone number, and an email. On the other hand, both KFUPM and PMU included more information. KFUPM, for example, includes a mailing address, a telephone number, an email, a map, and an online form to be filled out by those who could not find what they are looking for on the university's website. Moreover, PMU provided a mailing address, a telephone number, the university president's contact details, a map, the telephone numbers of some departments 
(e.g., finance department, operator, and housing department), and the emails of some departments (e.g., library, campus visit, housing services, enrollment, events, and human resources, to name but a few).

Analyzing the texts in this move, a discursive strategy has been noted; namely, the use of the imperative clause. This strategy, according to Askehave (2007, p. 736), is "an attention-seeking device known from promotional and advertising discourse." Moreover, the imperative usually "can maximally attract interested readers' attention and encourage them to give immediate and direct responses" (Zhang, 2017, p. 76). An example of this strategy is:

- Can't find what you're looking for? Ask a question (KFUPM)

\subsection{Showing Financial Stability}

Endowments assist universities to support their educational mission both in the present and in the future. Therefore, it is essential for universities to have endowments because they can help universities to excel academically and can be used in various ways: supporting research, improving academic programs, hiring excellent faculty members, providing grants, etc. As a result, this move can be used as a promotional strategy in higher education.

In the current study, two universities included this move: KSU and IU. The following excerpt clarifies how KSU perceives its endowment program:

- The endowment program will support research activities and initiatives to improve the educational and research process, and will extend support to university hospitals and health care services and medical research.

\subsection{Protecting User's Privacy}

The two universities that employed this move are KSU and KFUPM. Analyzing the texts in this move, it was found that a discursive strategy is used to gain readers' (prospective students') trust. One of the approaches used to gain their trust is through relationship with them, since building strong relationships with customers leads to faster growth (Whatley, 2018). These are just some examples of universities' attempts:

- This website does not save personal information about you when you visit it, unless you intentionally agree to provide us with your information. (KSU)

- According to regulations in Saudi Arabia, all authorized staff members are bound by law to keep all information safe and secure. (KSU)

- We will collect personal identification information from Users only if they voluntarily submit such information to us. (KFUPM)

In general, it can be said that similar to the Australian universities in Hoang and Rojas-Lizana's (2015) and in Giannoni's (2018) studies and to the 40 universities from the US, the UK, Australia and Canada in Yang's (2013) study, the Saudi universities use promotional discourse.

\section{Conclusion}

Incorporating Critical Discourse Analysis (CDA), the current study analyzed the "About Us" sections of seven Saudi universities' websites to explore the rhetorical moves and discursive strategies employed for marketization purposes. All of the universities examined featured on the top 1000 universities in the QS World University Rankings 2020. The findings show that the "About Us" sections are used by these universities as instruments for distinction and promotion. However, the results show diversity in universities" choice of implemented rhetorical moves and sub-moves. Out of eight moves and 13 sub-moves, only the "Vision, mission, values" sub-move was used in all universities in the current study.

While discursive strategies were employed for self-promotion, the universities need to use more discursive strategies for the purpose of marketization if they want to be truly global and compete with other international universities in the higher education market. Additionally, the presence of conversational dialogue demonstrates the university's attempts to develop a good partnership with prospective students. Such findings and recommendations of the current study should act as important guidance for universities concerning the influence of their online presence through their websites.

For future studies, researchers might conduct a case study on a particular university's website where they analyze all the content of that website. Researchers could also analyze multimodality (the various modes employed to create online messages) and/or intertextuality (the relationship of the used texts with other sections of the university's website). 


\section{References}

Alharbi, S. H. (2016). A discourse analysis of Arabic research articles in Islamic studies. International Journal of Language and Linguistics, 4(6), 198-206. https://doi.org/10.11648/j.ijll.20160406.12

Askehave, I. (2007). The impact of marketization on higher education genres: The international student prospectus as a case in point. Discourse Studies, 9(6), 723-742. https://doi.org/10.1177/1461445607082576

Berkenkotter, C., \& Huckin, T. N. (1993). Rethinking genre from a socio-cognitive perspective. Written Communication, 10(4), 475-509. https://doi.org/10.1177/0741088393010004001

Bhatia, V. K. (1993). Analysing genre: Language use in professional settings. London: Longman.

Bhatia, V. K. (1997). Genre analysis today. Revue Belge de Philologie et d'Histoire, 75(3), 629-652. https://doi.org/10.3406/rbph.1997.4186

Bhatia, V. K. (2002). Applied genre analysis: Analytical advances and pedagogical procedures. In A. M. Johns (Ed.), Genre in the classroom: Multiple perspectives (pp. 279-283). Mahwah, NJ: Erlbaum.

Connell, I., \& Galasinski, D. (1998). Academic mission statements: An exercise in negotiation. Discourse and Society, 9(4), 457-479. https://doi.org/10.1177/0957926598009004003

Cross, C., \& Oppenheim, C. (2006). A genre analysis of scientific abstracts. Journal of Documentation, 62(4), 428-446. https://doi.org/10.1108/00220410610700953

Dillon, A., \& Vaughan, M. (1997). 'It's the journey and the destination': Shape and the emergent property of genre in evaluating digital documents. New Review of Hypermedia and Multimedia, 3, 91-105. https://doi.org/10.1080/13614569708914685

Ding, H. (2007). Genre analysis of personal statements: Analysis of moves in application essays to medical and dental schools. English for Specific Purposes, 26, 368-392. https://doi.org/10.1016/j.esp.2006.09.004

Fairclough, N. (1992). Discourse and social change. Cambridge: Polity Press.

Fairclough, N. (1993). Critical discourse analysis and the marketisation of public discourse: The universities. Discourse \& Society, 4(2), 133-168. https://doi.org/10.1177/0957926593004002002

Fairclough, N. (1995). Critical discourse analysis: The critical study of language. London: Longman.

Fairclough, N. (2001). Language and power (2nd ed.). Harlow: Longman.

Giannoni, D. S. (2018). An investigation of value claims in academic and corporate 'About us' texts. Applied Linguistics, 39(3), 328-351. https://doi.org/10.1093/applin/amw010

Han, Z. R. (2014). The marketization of public discourse: The Chinese universities. Discourse \& Communication, 8(1), 85-103. https://doi.org/10.1177/1750481313503221

Hoang, T. V., \& Rojas-Lizana, I. (2015). Promotional discourse in the websites of two Australian universities: A discourse analytic approach. Cogent Education, 2(1). https://doi.org/10.1080/2331186X.2015.1011488

Jessee, A. (2009). Strategic stories: An analysis of the profile genre. Unpublished master's dissertation. Clemson University, Clemson, USA.

Jordan, M. P. (1986). Co-associative lexical cohesion in promotional literature. Journal of Technical Writing and Communication, 6, 33-53. https://doi.org/10.2190/B2T3-9P7J-TD84-7X7D

Kheovichai, B. (2014). Marketized university discourse: A synchronic and diachronic comparison of the discursive constructions of employer organizations in academic and business job advertisements. Discourse \& Communication, 8(4), 371-390. https://doi.org/10.1177/1750481314537575

Kwong, J. (2000). Introduction: Marketization and privatization in education. International Journal of Educational Development, 20(2), 87-92. https://doi.org/10.1016/S0738-0593(99)00060-7

Mayr, A. (2008). Language and power: An introduction to institutional discourse. London: Continuum.

Mazzarol, T. (1998). Critical success factors for international education marketing. International Journal of Educational Management, 12(4), 163-175. https://doi.org/10.1108/09513549810220623

Mišić-Ilić, B. (2014). Commercialization of academic values: The discourse of university mission statements. In V. Lopičić \& B. Mišić Ilić (Eds.), Values across cultures and times (pp. 171-193). Newcastle upon Tyne: Cambridge Scholars Publishing.

Muhlhausler, P., \& Harre, R. (1990). Pronouns and people: The linguistic construction of social and personal 
identity. Oxford, UK: Basil Blackwell.

Osman, H. (2008). Re-branding academic institutions with corporate advertising: A genre perspective. Discourse \& Communication, 2(1), 57-77. https://doi.org/10.1177/1750481307085577

Poonchako, K. (2017). Genre analysis of university online overviews: Analysis of moves in Japanese university online overviews. Unpublished MA dissertation. Thammasat University, Bangkok, Thailand.

Rust, A. A., \& Uys, C. S. (2014). The importance of a university identity for students and alumni: The case of the Cape Peninsula University of Technology, South Africa. Journal of Social Sciences, 40(1), 29-40. https://doi.org/10.1080/09718923.2014.11893300

Samraj, B., \& Monk, L. (2008). The statement of purpose in graduate program applications: Genre structure and disciplinary variation. English for Specific Purposes, 27(2), 193-211. https://doi.org/10.1016/j.esp.2007.07.001

Schlegelmilch, B. B., \& Pollach, I. (2005). The perils and opportunities of communicating corporate ethics. Journal of Marketing Management, 21, 267-290. https://doi.org/10.1362/0267257053779154

Shepherd, M., \& Watters, C. R. (1998). The evolution of cybergenres. Paper presented at the Proceedings of the Thirty-First Annual Hawaii International Conference on System Sciences (HICSS '98), Hawaii. https://doi.org/10.1109/HICSS.1998.651688

Swales, J. M. (1990). Genre analysis: English in academic and research settings. Cambridge: Cambridge University Press.

Swales, J. (2004). Research genres-exploration and application. Cambridge: Cambridge University Press. https://doi.org/10.1017/CBO9781139524827

Symonenko, S. (2007). Websites through genre lenses: Recognizing emergent regularities in websites' content structure (Order No. 3266321). Available from ProQuest Dissertations \& Theses Global. (304781774). Retrieved from https://search-proquest-com.sdl.idm.oclc.org/docview/304781774?accountid=142908

Teo, P. (2007). The marketisation of higher education: A comparative case-study of two universities in Singapore. Critical Approaches to Discourse Analysis Across Disciplines, 1(1), 95-111.

Tomarkova, R. (2015). A walk through the multimodal landscape of university websites. Brno Studies in English, 41(1), 77-100. https://doi.org/10.5817/BSE2015-1-5

Toms, E. G., \& Campbell, D.G. (1999). Genre as interface metaphor: Exploiting form and function in digital environments [CD-ROM] (ddgen06.ps). In Proceedings of the 32nd Annual Hawaii International Conference on Systems Sciences, January 5-8, 1999, Maui.

Watkins, B. A., \& Gonzenbach, W. J. (2013). Assessing university brand personality through logos: An analysis of the use of academics and athletics in university branding. Journal of Marketing for Higher Education, 23(1), 15-33. https://doi.org/10.1080/08841241.2013.805709

Whatley, T. (2018, September 7). How to build strong customer relationships to boost retention. The Daily Egg. Retrieved from https://www.crazyegg.com/blog/customer-relationships-boost-retention/

Xiong, T. (2012). Discourse and marketization of higher education in China: The genre of advertisements for academic posts. Discourse \& Society, 23(3), 318-337. https://doi.org/10.1177/0957926511433786

Yang, W. (2013). "Why choose us?" Text in university websites: A genre analysis. Taiwan International ESP Journal, 5(1), 45-80.

Zhang, T. (2017). The marketization of higher education discourse: A genre analysis of university website homepages in China. Higher Education Studies, 7(3), 64-79. https://doi.org/10.5539/hes.v7n3p64

Zhang, Y., \& O’Halloran, K. L. (2013). Toward a global knowledge enterprise: University websites as portals to the ongoing marketization of higher education. Critical Discourse Analysis, 10(4), 468-485. https://doi.org/10.1080/17405904.2013.813777

\section{Copyrights}

Copyright for this article is retained by the author, with first publication rights granted to the journal.

This is an open-access article distributed under the terms and conditions of the Creative Commons Attribution license (http://creativecommons.org/licenses/by/4.0/). 